\title{
Removal efficiency of the dinoflagellate Heterocapsa triquetra by phosphatic clay, and implications for the mitigation of harmful algal blooms
}

\author{
Marie-Claude Archambault ${ }^{1, *}$, Jon Grant ${ }^{1}$, V. Monica Bricelj ${ }^{2}$ \\ ${ }^{1}$ Department of Oceanography, Dalhousie University, 1355 Oxford Street, Halifax, Nova Scotia B3H 4J1, Canada \\ ${ }^{2}$ Institute for Marine Biosciences, National Research Council of Canada, 1411 Oxford Street, Halifax, \\ Nova Scotia B3H 3Z1, Canada
}

\begin{abstract}
An increased incidence of harmful algal blooms (HABs) has been reported in nearshore coastal waters, including economically important aquaculture sites worldwide. This has generated interest in using ecologically inert clays as a means of mitigating HABs at relatively shallow enclosed mariculture sites. This proposed mitigation measure assumes that flocculation and accelerated sedimentation of large algal cells (dinoflagellates) occurs with the application of clays. The objective of the current research was to characterize suspended clay-algal interactions and in situ particle size in a laboratory application of the phosphatic clay IMC-P $(1.8 \mu \mathrm{m}$ mean equivalent spherical diameter, ESD) to a simulated Heterocapsa triquetra (14.7 $\mu \mathrm{m}$ mean ESD) bloom. Flow speed was adjusted to provide 2 contrasting regimes (mimicking possible field conditions). This research was conducted in a recirculating flume and used a novel in situ device, the small volume particle microsampler (SVPM), for particle size characterization. Results indicated that $100 \%$ of the thecate dinoflagellate $H$. triquetra was removed in $48 \mathrm{~h}$ by IMC-P in a low-flow $\left(<2 \mathrm{~cm} \mathrm{~s}^{-1}\right)$ regime, but remained in the water column in the high-flow ( $>13 \mathrm{~cm} \mathrm{~s}^{-1}$ ) regime. The mechanism for algal removal is equivocal since SVPM filter photographs indicated that clay aggregated to form particles $>3 \mu \mathrm{m}$, but did not aggregate with algal cells under the experimental conditions tested. At this particle size, the clay aggregates become available for retention with $100 \%$ efficiency on the gills of suspension-feeding bivalves, which could be seriously affected by the increased particle flux to the bottom. The mechanism of cell removal by clays has not been identified; however, it may occur via direct effects of clay on cell surface properties and swimming ability. Further investigations on the removal mechanism are required to predict the fate of cells in a field application of clay.
\end{abstract}

KEY WORDS: Harmful algal blooms · Clay · Particle size distribution - Small volume particle microsampler $\cdot$ Heterocapsa triquetra $\cdot$ Mitigation $\cdot$ Aggregation

\section{INTRODUCTION}

Harmful algal blooms (HABs) have increased in their global geographic spread in recent decades (Hallegraeff 1993). In North America, this has prompted research on control and mitigation methods in an effort to reduce the ecological and economic impacts on economically important fisheries and nearshore mariculture operations (Anderson 1997). One of these methods involves the use of ecologically inert clays to control prolific HABs, such as neurotoxic blooms of Karenia brevis (formely Gymnodinium breve) in Florida, USA. Clays are relatively inexpensive, can be supplied in large quantities as industrial waste products from mining and drilling operations (Sengco et al. 2001), and are presumed to have little or no direct toxic effects on aquatic organisms (Howell \& Shelton 1970, Portman 1970). Clay application is currently being used extensively at fish aquaculture sites in South Korea to control Cochlodinium polykrikoides blooms ( $\mathrm{Na}$ et al. 1996, Bae et al. 1998, Kim 1998). In 1996, approximately $60000 \mathrm{t}$ of dry loess clay were dispersed over a 
bloom-affected area $\left(260 \mathrm{~km}^{2}\right)$ at an estimated surface aerial loading rate of $400 \mathrm{~g} \mathrm{~m}^{-2}$. Removal rates of $C$. polykrikoides from the upper $2 \mathrm{~m}$ of the water column were estimated at 90 to $99 \%$ (Na et al. 1996). No mortality of cultured yellowtail Seriola quinqueradiata was reported and the bloom did not return for the remainder of the season. This method was originally used by Avnimelech \& Menzel (1984) in low salinity impoundments, and showed that turbid ponds were clarified by the coflocculation of algae and clay.

The reasoning behind the proposed mitigation effort invokes the flocculation and accelerated sedimentation of large algal cells (dinoflagellates) via the application of clays (Avnimelech et al. 1982, Degens \& Ittekot 1984). The process of flocculation consists of 2 discrete steps: transport and attachment (Thomas et al. 1999). The transport step, leading to the collision of 2 particles, is achieved by virtue of local variations in fluid particle velocities. Particle theory identifies several mechanisms by which collisions increase the likelihood that particles will come into contact with each other and effectively aggregate. The 3 main mechanisms are Brownian diffusion, fluid shear (laminar or turbulent) and differential sedimentation (Thomas et al. 1999, Sengco 2001). The dominant collision mechanism changes with particle size: Brownian diffusion is important when particles are $<1 \mu \mathrm{m}$, while fluid motion begins to dominate for larger particles, depending on the shear rate (McCave 1984a). Jackson \& Lochmann (1993) suggested that in a system with flagellated organisms, like many that produce HABs, particle collisions are also generated by swimming. Sengco (2001) calculated that total collision frequency and algal removal were significantly greater in the presence of flagellates than non-motile diatoms and small cocci. Attachment is contingent upon a number of shortrange forces largely pertaining to the nature of the surfaces themselves (Thomas et al. 1999).

Transparent exopolymer particles (TEP) have been identified recently and postulated to be essential to the flocculation of diatom blooms and the formation of large settling aggregates (Alldredge et al. 1993, Passow et al. 1994). However, TEP is rarely produced in large quantities by dinoflagellates (common constituents of HABs) and is not considered to be a mechanism for aggregation in such blooms (Alldredge et al. 1993, 1998; Passow \& Alldredge 1994). Detailed studies on the possible mechanisms of clay-cell flocculation have been pursued by Avnimelech et al. (1982) and Søballe \& Threlkeld (1988). The resulting large aggregated particles have greater settling velocities than smaller unflocculated particles (McCave 1984b). Flocs can also capture more cells as they sink and thus, sweep and entrain particles through the water column.
Clay application is presently being tested experimentally as a potential method for controlling HABs in the United States (ECOHAB research, Woods Hole Oceanographic Institution, Sengco et al. 2001). However, this research on clay-algal flocculation and removal efficiency has been conducted in small scale $(10 \mathrm{ml}$ test tubes) static systems, i.e. no flow, showing that clays have specific removal efficiencies depending on the phytoplankton species and cell concentration (Yu et al. 1994a,b, 1995, 1999, Kim 1998, Choi et al. 1999, Sengco et al. 2001). For example, Sengco et al. (2001) determined the removal efficiency of many clay types, including montmorillonites, bentonites and kaolinites, applied to Karenia brevis and the brown tide picoplankter Aureococcus anophagefferens in test tubes.

The objectives of the current research were: (1) to characterize suspended clay-algal interactions and in situ particle size in a laboratory application of clay to a simulated $\mathrm{HAB}_{\text {; }}$ and (2) to determine the effects of flow on particle (clay and algae) removal. Fluid shear dominates particle contact rates when particles are $>1 \mu \mathrm{m}$ (McCave 1984a) and tears apart aggregates when it is too high at the particle surface (Eisma 1986, Dyer \& Manning 1999, Manning \& Dyer 1999). Therefore, it was important to include shear to understand if and how aggregates are formed or destroyed, and how this will affect the particle size distribution and sinking rates. Examination of the effectiveness of dinoflagellate cell removal by clay in flowing water has recently been conducted in a large-scale flume (S. E. Beaulieu, M. R. Sengco \& D. M. Anderson unpubl. data), but aggregate size characterization was not attempted.

The present research was conducted in a recirculating flume that allowed for flow adjustment and used a novel in situ device, the small volume particle microsampler (SVPM, Archambault et al. 2001), for particle size characterization. Although aggregation has been observed during laboratory applications of clay to HABs and is theorized as the removal mechanism, past efforts have not quantified the in situ particle size spectrum. This information provided by the SVPM was also useful in interpreting results of concurrent research on the effects of this mitigation strategy on the growth of the hard clam Mercenaria mercenaria, and allow general predictions about the availability of clay particles to suspension-feeding bivalves exposed to this treatment in the field (Archambault 2002).

\section{MATERIALS AND METHODS}

Sequential paired experiments were conducted to determine the efficiency of removal of a HAB species subjected to an application of clay dispersion at 2 flow 
regimes. Preliminary trials were conducted to determine the experimental flow conditions, optimal clay and algal concentrations, and various instrument calibrations. The 2 selected flow regimes represent contrasting conditions in the field where low flow characterizes a low-energy environment that encourages complete sedimentation and high flow characterizes a high-energy environment that maintains particle suspension.

Experimental setup. Experiments were conducted using a small recirculating seawater flume $(1.5 \mathrm{~m}$ long $\times 0.2 \mathrm{~m}$ wide $\times 0.25 \mathrm{~m}$ high) in the Aquatron facility at Dalhousie University, Halifax, Nova Scotia (Pilditch et al. 1998) (Fig. 1). Ambient seawater at 32 psu was supplied from the Northwest Arm of the harbor by the Aquatron, through a series of pumps and filters, to obtain $0.22 \mu \mathrm{m}$ filtered seawater (FSW). At a $0.20 \mathrm{~m}$ water depth, the total capacity of the flume was $90 \mathrm{l}$. The working area, located $0.9 \mathrm{~m}$ downstream, was $0.25 \mathrm{~m}$ long $\times 0.15 \mathrm{~m}$ wide $\times 0.10 \mathrm{~m}$ deep and was filled with well sorted clean beach sand. An insulated recirculating water jacket controlled by a heating-cooling system pumped temperature-regulated seawater around the perimeter of the flume. An insulating cover limited heat loss and ambient light to a $12 \mathrm{~cm}$ diameter porthole on the side of the flume and $10 \mathrm{~cm}$ square on top of the cover. Water entering the flume through a $10 \mathrm{~cm}$ (in diameter) pipe, was rectified by 2 polycarbonate core flow straighteners $(0.64 \mathrm{~cm}$ in diameter, $1.27 \mathrm{~cm}$ in width) (Plascore) located at 5 and $25 \mathrm{~cm}$ downstream of the entrance. An airline was inserted in the return flow pipe for gentle water aeration. At $1.35 \mathrm{~m}$ downstream, water exits the flume and enters the descending arm of the return pipe, where a propeller drives the flow. Flow speeds can range from 0 to $30 \mathrm{~cm} \mathrm{~s}^{-1}$, with sufficient shear stress to resuspend sand size sediments at higher flows (Pilditch et al. 1998). The propeller motor is regulated by a rheostat from which values of 500, 1000 and 2000 rpm were selected; these correspond to current speeds (10 $\mathrm{cm}$ above bottom) of $1.8 \pm 0.02($ mean $\pm \mathrm{SD}), 5.7 \pm 1.3$ and $13.6 \pm 2.7 \mathrm{~cm} \mathrm{~s}^{-1}$, respectively, as determined using a Nixon Streamflo ${ }^{\circledR}$ current meter calibrated on a rotating arm in a circular tank (Stewart 1999). Because of a short horizontal distance, the flume tends to have a central jet due to flow from the incoming pipe. The height of $10 \mathrm{~cm}$ above bottom corresponds to the center of the jet.
Particles. The thecate dinoflagellate Heterocapsa triquetra (Strain Het, $14.7 \pm 2.2 \mu \mathrm{m}$ equivalent spherical diameter [ESD]) (Fig. 2A) was grown in batch cultures in 201 carboys in modified L1 medium (Guillard \& Hargraves 1993, $50 \mu \mathrm{M} \mathrm{NH} \mathrm{NH}_{4} \mathrm{Cdded)}$ at $16^{\circ} \mathrm{C}$ under 14:10 h light:dark cycle. The removal experiments were performed using cultures in mid- to lateexponential growth phase. Heterocapsa triquetra was chosen as a non-toxic proxy for toxic dinoflagellates, such as Karenia brevis. This species can be grown easily in large quantities and has previously been shown to be removed effectively by the supplied phosphatic clay IMC-P (see below) (M. R. Sengco pers. comm.). The concentration of $H$. triquetra used in the trials was 4000 cells $\mathrm{ml}^{-1}$, as cells at this concentration have been shown to be efficiently removed (>80\%) by IMC-P in smaller scale static trials (M. R. Sengco pers. comm.). Typical bloom concentrations reported for $H$. triquetra in the field range from 2000 (Kim et al. 1993) to 5000 cells $\mathrm{ml}^{-1}$ (Lindholm \& Nummelin 1999). Prior to the trials conducted with $H$. triquetra, the batch was moved to a $20^{\circ} \mathrm{C}$ room with $24 \mathrm{~h}$ light for acclimation to prevent temperature shock. Algal stock concentrations were measured using a Coulter Multisizer (Model II, $100 \mu \mathrm{m}$ aperture). In the clay and algae trials, H. triquetra was added to the flume downstream of the working area and allowed to mix for $1 \mathrm{~min}$ at $5.7 \mathrm{~cm}$ $\mathrm{s}^{-1}$. Prior to the addition of clay and flow adjustment, an initial sample of the algal suspension was taken $10 \mathrm{~cm}$ off the bottom with a $10 \mathrm{ml}$ micropipette and counted by microscope to determine the accuracy of the stock dilution. Cell motility (Fig. 3) was qualitatively as-

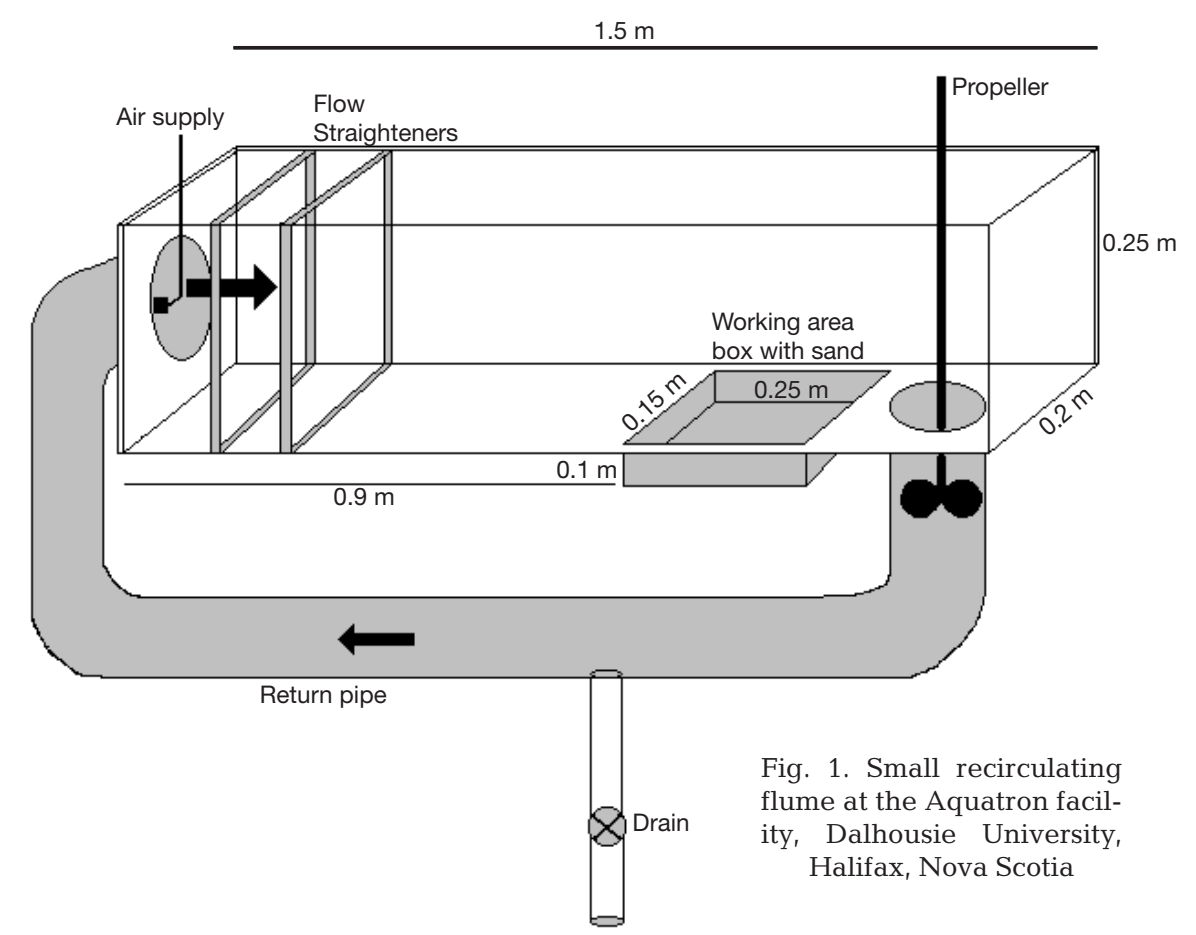



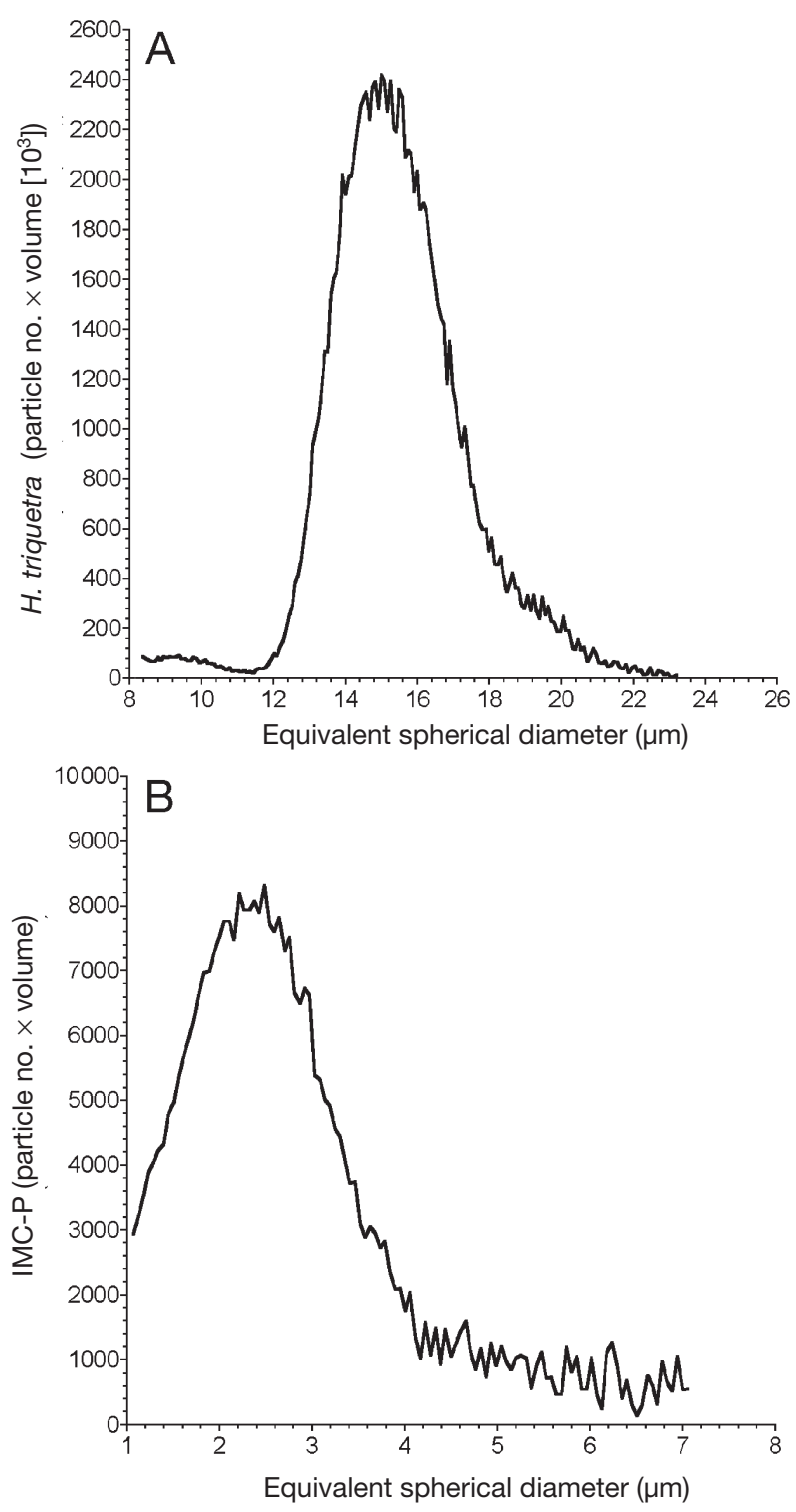

Fig. 2. Coulter Multisizer size distributions as the product of particle number and volume by equivalent spherical diameter (ESD). (A) Thecate dinoflagellate Heterocapsa triquetra size distribution (14.7 $\pm 2.2 \mu \mathrm{m}$ ESD). (B) Phosphatic clay IMC-P particle number times volume distribution $(2.7 \pm 1.0 \mu \mathrm{m}$ ESD). The mean particle size from the particle number distribution is $1.8 \pm 0.7 \mu \mathrm{m} \mathrm{ESD}$

sessed as relative proportions of total cells moving in a Palmer-Maloney counting chamber $(0.1 \mathrm{ml})$ under a compound microscope, where $\mathrm{H}, \mathrm{M}$ and $\mathrm{L}$ indicate a high, medium and low proportion of actively swimming cells respectively.

The phosphatic clay IMC-P $(1.8 \pm 0.7 \mu \mathrm{m}$ ESD, $50 \%$ water content; Fig. 2B shows the particle number $\times$ volume distribution) was used for the removal of Heterocapsa triquetra in the clay treatment trials. The montmorillonite phosphatic clay IMC-P (IMC Phosphates) is
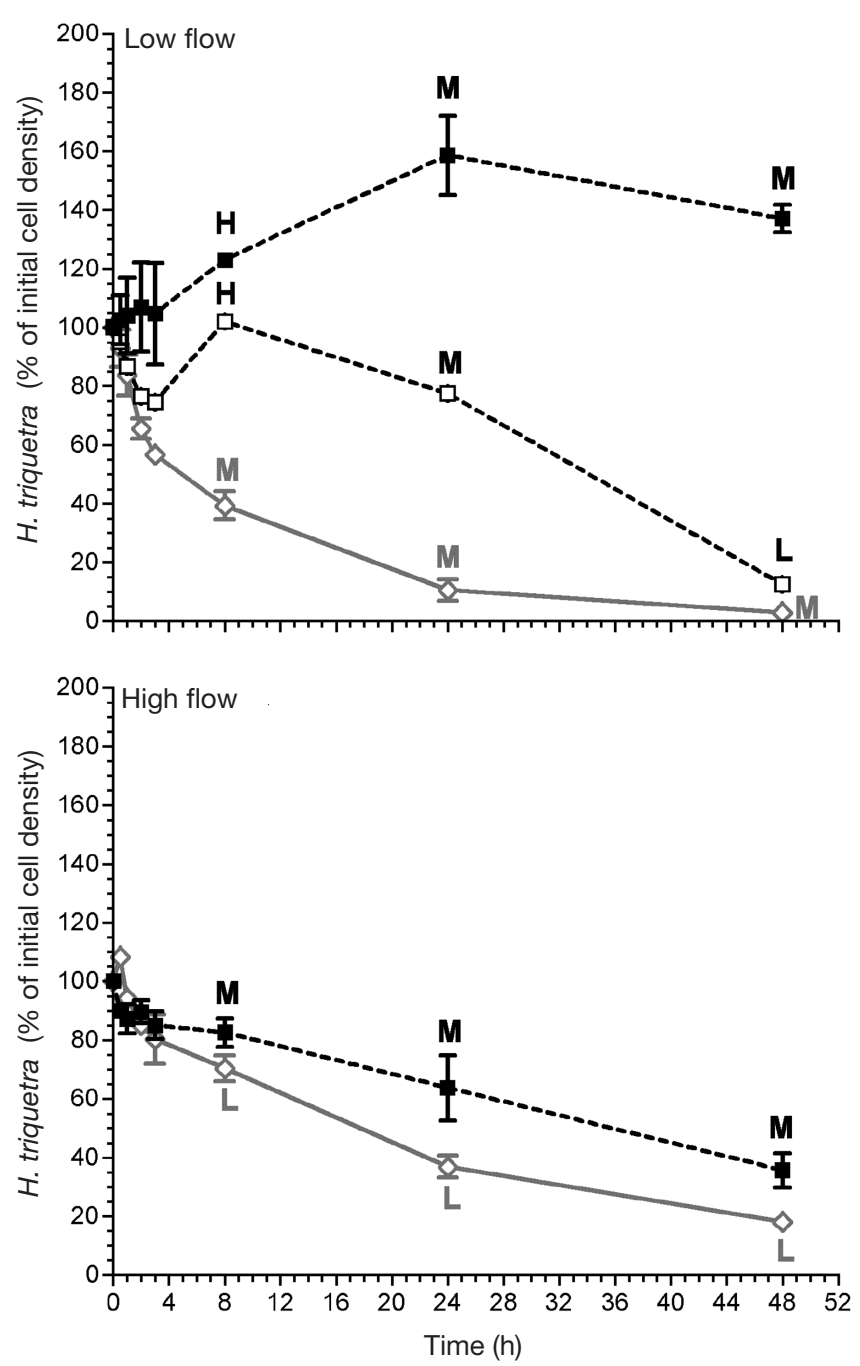

Fig. 3. Heterocapsa triquetra removal efficiency by the phosphatic clay IMC-P, as the \% of algal cells remaining in the water column relative to the initial cell concentration over $48 \mathrm{~h}$. Algae-only control, no IMC-P present 2 trials averaged $(\square)$; algae-only controls, no IMC-P present $(\square)$; clay-algae treatment, IMC-P present at $0.25 \mathrm{~g} \mathrm{DW}^{-1}(\diamond)$. The letters indicate a qualitative measure of algal cell swimming ability, where $\mathrm{H}, \mathrm{M}$ and $\mathrm{L}$ indicate a high, medium and low proportion of cells actively swimming, respectively. Error bars are $\mathrm{SE}$ on triplicate trials

produced in large quantities as an industrial waste product from the phosphate mining industry and is composed of 30 to $50 \%$ silt/sand and up to two-thirds $<2 \mu \mathrm{m}$ size fraction (Bromwell 1982). The clay displays strong propensity for exchanging ions in its crystal structure (Sengco 2001). It was prepared for experiments by processing $45 \mathrm{~g}$ wet weight (WW) of clay in $900 \mathrm{ml}$ of 18 to $20^{\circ} \mathrm{C}$ flume seawater in a blender at high speed for 2 min and sieving through a $63 \mu \mathrm{m}$ stainless steel mesh to produce a fine particle slurry. 
This process is comparable to WHOI procedures for laboratory experiments and for future field trials (M. R. Sengco pers. comm.). The final clay suspension added to the flume (90 l) was $0.25 \mathrm{~g}$ dry weight (DW) $\mathrm{l}^{-1}$. This IMC-P concentration was used because it was the minimum concentration shown to remove $H$. triquetra efficiently (>80\%) in static test tube trials (M. R. Sengco pers. comm.). Preliminary trials indicated that when deposited this clay suspension produced a substantial sediment layer 4 to $5 \mathrm{~mm}$ in depth. Following the addition of $H$. triquetra, the slurry was added downstream of the working area and mixed through the water column at a flow of $5.7 \mathrm{~cm} \mathrm{~s}^{-1}$ for 1 min prior to any change in experimental flow conditions. This time was defined as time 0 .

Experimental design. Paired sequential experimental trials $(\mathrm{n}=3$ ) included an algae-only control (Heterocapsa triquetra) and clay-algae treatment (IMC-P and $H$. triquetra). This experimental design was implemented to determine the effectiveness of IMC-P in removing $H$. triquetra from the water column $(0.22 \mu \mathrm{m}$ FSW, $20^{\circ} \mathrm{C}$ ) in 2 flow regimes. A clay-only control was also conducted in both flow regimes to determine the clay particle characteristics in the absence of algae. Two flow conditions, low and high, were chosen to reflect contrasting conditions in the field, where the low-flow regime $\left(1.8 \pm 0.2 \mathrm{~cm} \mathrm{~s}^{-1}\right)$ characterizes a lowenergy environment that encourages complete sedimentation of the clay and algae, and the high-flow regime $\left(13.6 \pm 2.7 \mathrm{~cm} \mathrm{~s}^{-1}\right)$ characterizes a high-energy environment which maintains clay in suspension. Trials and combinations of conditions, with the variables measured per trial, are identified in Table 1.

The removal efficiency of Heterocapsa triquetra was quantified as the percent of initial cell numbers remaining in the water column over time, determined with a
$0.1 \mathrm{ml}$ Palmer-Maloney counting chamber under a compound microscope. The removal efficiency of IMC-P from the water column was quantified as the percent of the initial suspended particulate matter (SPM) concentration remaining in the water column over time, using an optical backscatter (OBS) probe positioned in the middle of the water column (10 cm offbottom). The IMC-P concentration was assumed to be $\sim 100 \%$ of the total SPM, given that algal cells were rare compared to clay particles and that the OBS could not distinguish the cells. The OBS was calibrated using known dry weight concentrations of IMC-P suspensions determined by filtering known volumes through GF/F filters. The probe face was cleaned occasionally with a soft brush to dislodge any buildup of particles on the sensor. The data shown were adjusted by removing the portions of the logged record affected by particle buildup.

Particles were captured and their size distributions were analyzed using the small volume particle microsampler (SVPM) described in Archambault et al. (2001) and image analysis specified below. The SVPM is a sampling device that captures a $1 \mathrm{ml}$ sample and its individual particles in situ on filters with minimal disturbance. It is especially effective in capturing particles in the size categories that are ineffectively sampled by most in situ cameras $(<50 \mu \mathrm{m})$ (Archambault et al. 2001). Each trial lasted $48 \mathrm{~h}$, and SVPM and algal samples were obtained at 0, 0.5, 1, 2, 3, 8, 24 and $48 \mathrm{~h}$ for the algae-only and algae-clay trials, and 0,3 , 24 and $48 \mathrm{~h}$ for the clay-only control trials. Data for the particle size distributions from times 3 and $24 \mathrm{~h}$ are reported.

In the low-flow trials, material sedimented to the flume bed was collected after $48 \mathrm{~h}$ using three $10 \mathrm{ml}$ beakers acting as sediment traps positioned down-

Table 1. Summary of experimental trials characterizing particle aggregates

\begin{tabular}{|c|c|c|c|c|}
\hline Condition & Treatment & $\begin{array}{l}\text { Heterocapsa triquetra } \\
\text { density }\left(\text { cells ml } \mathrm{ml}^{-1} \text { ) }\right.\end{array}$ & $\begin{array}{l}\text { IMC-P concentration } \\
\left(\mathrm{g} \mathrm{DW} \mathrm{l}^{-1}\right)\end{array}$ & Variables measured \\
\hline \multirow{3}{*}{$\begin{array}{l}\text { Low flow } \\
\left(1.8 \mathrm{~cm} \mathrm{~s}^{-1}\right)\end{array}$} & Algae-only (Control) & 4000 & 0 & Removal efficiency of $H$. triquetra \\
\hline & Clay-only (Control) & 0 & 0.25 & $\begin{array}{l}\text { Removal efficiency of IMC-P } \\
\text { Particle size } \\
\text { Clay loading }\end{array}$ \\
\hline & Clay-algae & 4000 & 0.25 & $\begin{array}{l}\text { Removal efficiency of } H \text {. triquetra } \\
\text { Removal efficiency of IMC-P } \\
\text { Particle size } \\
\text { Clay loading }\end{array}$ \\
\hline \multirow{3}{*}{$\begin{array}{l}\text { High flow } \\
\left(13.7 \mathrm{~cm} \mathrm{~s}^{-1}\right)\end{array}$} & Algae-only (Control) & 4000 & 0 & Removal efficiency of $H$. triquetra \\
\hline & Clay-only (Control) & 0 & 0.25 & $\begin{array}{l}\text { Removal efficiency of IMC-P } \\
\text { Particle size }\end{array}$ \\
\hline & Clay-algae & 4000 & 0.25 & $\begin{array}{l}\text { Removal efficiency of } H \text {. triquetra } \\
\text { Removal efficiency of IMC-P } \\
\text { Particle size }\end{array}$ \\
\hline
\end{tabular}


Table 2. ANOVA on the removal efficiency of Heterocapsa triquetra by IMC-P clay over times $0,3,24$ and $48 \mathrm{~h}$. Treatment conditions are: algae-only controls and clay-algae trials for both low and high flows

\begin{tabular}{|lrrrrr|}
\hline & df & SS & MS & F-ratio & p-value \\
\hline A: Time & 7 & 2.82 & 0.40 & 20.58 & $<0.001^{*}$ \\
B: Treatment & 3 & 1.70 & 0.57 & 28.96 & $<0.001^{*}$ \\
AB & 21 & 1.62 & $7.71 \times 10^{-2}$ & 3.93 & $<0.001^{*}$ \\
Error & 64 & 1.25 & $1.96 \times 10^{-2}$ & & \\
Total (adjusted) & 95 & 7.40 & & & \\
Total & 96 & & & & \\
*Significant at $\alpha=0.05$ & & & & \\
& & & & & \\
\hline
\end{tabular}

stream of the working area during the clay-only and clay-algae treatments. Bottom clay loading was measured by filtering the collected sediment on preweighed glass fiber filters $(2.5 \mathrm{~cm} \mathrm{GF} / \mathrm{F}, 0.2 \mu \mathrm{m}$ pore size) and drying in an $80^{\circ} \mathrm{C}$ oven for $24 \mathrm{~h}$. Filters were weighed, and sediment mass was calculated and then converted to $\mathrm{g}$ DW $\mathrm{m}^{-2}$.

Imaging technique. Photographs of SVPM filters (20 fields of view [FOV] per filter, $7 \%$ of the filter area) were taken under a Leitz Laborlux D fluorescence microscope $(10 \times$ Fluotar objective, 100× magnification) with a Megaplux Camera Model 1.4i (Kodak) and the XCAP-LITE v.0.5B frame grabber software (Epix). Each field of view was photographed under both light and fluorescence (excitation 270 to $380 \mathrm{~nm}$, emission 410 to $580 \mathrm{~nm}$ filter), to capture algal cells and clay particles simultaneously. Microscope resolution at this magnification was a particle diameter of $1.94 \mu \mathrm{m}$, based on a convention of 3 screen pixels (Russ 1995). The SVPM filters were placed on CytoClear slides (Osmonics), which eliminated background filter noise and allowed for higher particle resolution. Photographs were analyzed with SigmaScan Pro version 5.0 (SPSS). To minimize any observer bias associated with image analysis, e.g. 'blooming' of the image and differences in illumination, all photographs were enhanced (intensity, contrast) equally.

Particle area was quantified and converted to the equivalent circular diameter (ECD) $(\mu \mathrm{m})$, the diameter of the particle assuming a 2-dimensional circular shape. The ESD is the diameter of a particle assuming a 3-dimensional sphere. Particle distributions are expressed as the product of the number of particles and the particle volume per ECD bin size. To distinguish algal cells from large aggregates in the particle size spectrum, the fluorescence images were used to determine those particles known to be algal cells and to delete them from the distribution. Control photographs using filtered seawater indicated that SVPM filter photographs did not require correction for noise or extraneous particles.
Statistical analyses. All statistical analyses were conducted using NCSS 2000 software (www.ncss.com). The data were tested for normality and transformed before performing 2-way analyses of variance (ANOVA) with flow and particle types as the treatments (Table 2), and regressions (linear and nonlinear) were used to compare the rate of loss (algae and clay) in each trial. Data that violated normality and could not be transformed were subjected to the Kolmogoroff-Smirnoff non-parametric test for differences in distributions.

\section{RESULTS}

\section{Heterocapsa triquetra removal efficiency}

Experiments conducted under the low-flow regime indicated a rapid removal of Heterocapsa triquetra from the water column in the presence of IMC-P, but not in the algae-only controls. The mean of the first 2 algae-only trials indicated that in this flow regime there was an increase in cell concentration, indicative of algal growth, with little removal of the cells over time (Fig. $3 ; \mathbf{\square}$ ). There was also a high-to-medium proportion of cells swimming. The third algae-only control, however, showed that after $8 \mathrm{~h}$, a progressive decrease in the proportion of motile cells was associated with a higher net removal of $H$. triquetra cells from the water column than in the 2 previous controls (Fig. 3 ; ㅁ). Removal from the water column may have been accelerated in the anomalous control by poor overall condition of the cell culture, which may have resulted in a higher percentage of non-motile and senescing cells. Had loss in the system occurred via other mechanisms, i.e. capture by flow straighteners or return pipe, it would have been consistent in the first 2 controls. In direct contrast to the algae-only controls, the clay-algae trials indicated that there was an exponential decline described by:

$$
C_{t}=C_{0} \exp (-k t)
$$

where $C_{t}$ is the $\%$ algal concentration at time $t(\mathrm{~h}), C_{0}$ is the \% initial algal concentration and $k$ is the exponential decay rate $\left(\% \mathrm{~h}^{-1}\right)$ in $H$. triquetra cell concentration in the water column over time (slope $=-0.16 \%$ $\left.\mathrm{h}^{-1}, \mathrm{R}^{2}=0.95\right)$. Algal concentrations were reduced by $90 \%$ in $24 \mathrm{~h}$ and over the $48 \mathrm{~h}$ of the experiment, a total of $95 \%$ of $H$. triquetra cells were removed from the water column in the presence of IMC-P clay. The algal cells showed moderate swimming ability in the presence of IMC-P, in contrast to high motility observed at $8 \mathrm{~h}$ in the algae-only controls, and were not able to maintain net growth or remain suspended in the water column. 
In the high-flow regime algae-only controls, there was a gradual decline of Heterocapsa triquetra cell concentration with a medium proportion of actively swimming cells in the water column over time (Fig. 3). High shear at this flow regime may have resulted in reduced cell motility compared to the $8 \mathrm{~h}$ algae-only control in the low-flow regime. Over the $48 \mathrm{~h}$ of the experiment the initial dinoflagellate concentration was reduced by $60 \%$. The clay-algae treatments indicated that in the presence of clay, cells consistently showed low motility and over $48 \mathrm{~h}, 80 \%$ of the cells were removed.

A 2-factorial (Table 2) and Bonferroni post-hoc comparisons indicated that there was a significant effect of the presence of clay on dinoflagellate removal efficiency in the low-flow regime $(p<0.001)$, and a significant effect of flow speed between algae-only controls $(\mathrm{p}<0.001)$ and between clay-algae treatments $(p<0.001)$ for both flow types. However, there was no significant effect of the presence of clay between the algae-only controls and clay-algae treatments in the high-flow regime $(p=0.236)$. Thus, clay significantly enhanced dinoflagellate removal relative to controls, but only at the low flow.

\section{SPM removal efficiency}

Paired experiments of clay-only control and clayalgae treatment (IMC-P and Heterocapsa triquetra present) were compared in terms of the mean depletion of SPM for all trials recorded by optical backscatter (Fig. 4). Optical backscatter measurements in low flow indicated that approximately $50 \%$ of the sediment load was removed within the first $8 \mathrm{~h}$ regardless of the presence of $H$. triquetra (Fig. 4). The data were fitted with an exponential decay function:

$$
\left(C_{t}-C_{\infty}\right) /\left(C_{0}-C_{\infty}\right)=\exp (-k t)
$$

where $C_{t}$ is SPM as the \% initial concentration at time $t(\mathrm{~h}), C_{\infty}$ is the asymptotic steady state concentration approached as time goes to infinity, $C_{0}$ is the \% initial concentration and $k$ is the exponential decay rate $\left(\% \mathrm{~h}^{-1}\right)$. The presence of algal cells did not significantly accelerate the exponential decrease in SPM, as tested by the overlap of the $95 \%$ confidence limits (CI), where the decay rates at low flow were $0.07 \% \mathrm{~h}^{-1}\left(\mathrm{R}^{2}=0.99\right)$ and $0.10 \% \mathrm{~h}^{-1}\left(\mathrm{R}^{2}=0.99\right)$ for the clay-only control and clay-algae treatment, respectively. At the end of the $48 \mathrm{~h}$ trial, the total SPM removal for the low-flow trials were approximately 82 and $88 \%$ of the original concentration for the clay-only control and mean of the clay-algae trials, respectively.

The deposited particulate matter in the low-flow regimes was not significantly different between the clay-only control and the combined clay-algae treatments $(p=0.437, F=0.66, d f=1)$. The clay-only control indicated an average bottom clay loading of $13.2 \pm$ $1.8 \mathrm{~g} \mathrm{~m}^{-2}$, compared to a mean clay loading of $13.9 \pm$ $1.1 \mathrm{~g} \mathrm{~m}^{-2}$ for the combined clay-algae trials. All trials produced a sedimented clay layer of approximately $4 \mathrm{~mm}$ in depth.

In the high-flow regime, the bulk of the particulate matter remained in suspension regardless of the presence of Heterocapsa triquetra (Fig. 4). The greatest loss occurred during the first $8 \mathrm{~h}$, with decay rates (fitted by Eq. 2) of $0.16 \% \mathrm{~h}^{-1}\left(\mathrm{R}^{2}=0.89\right)$ and $0.08 \% \mathrm{~h}^{-1}$ $\left(\mathrm{R}^{2}=0.85\right)$ for the clay-only control and clay-algae treatment, respectively. Potential losses in the flume
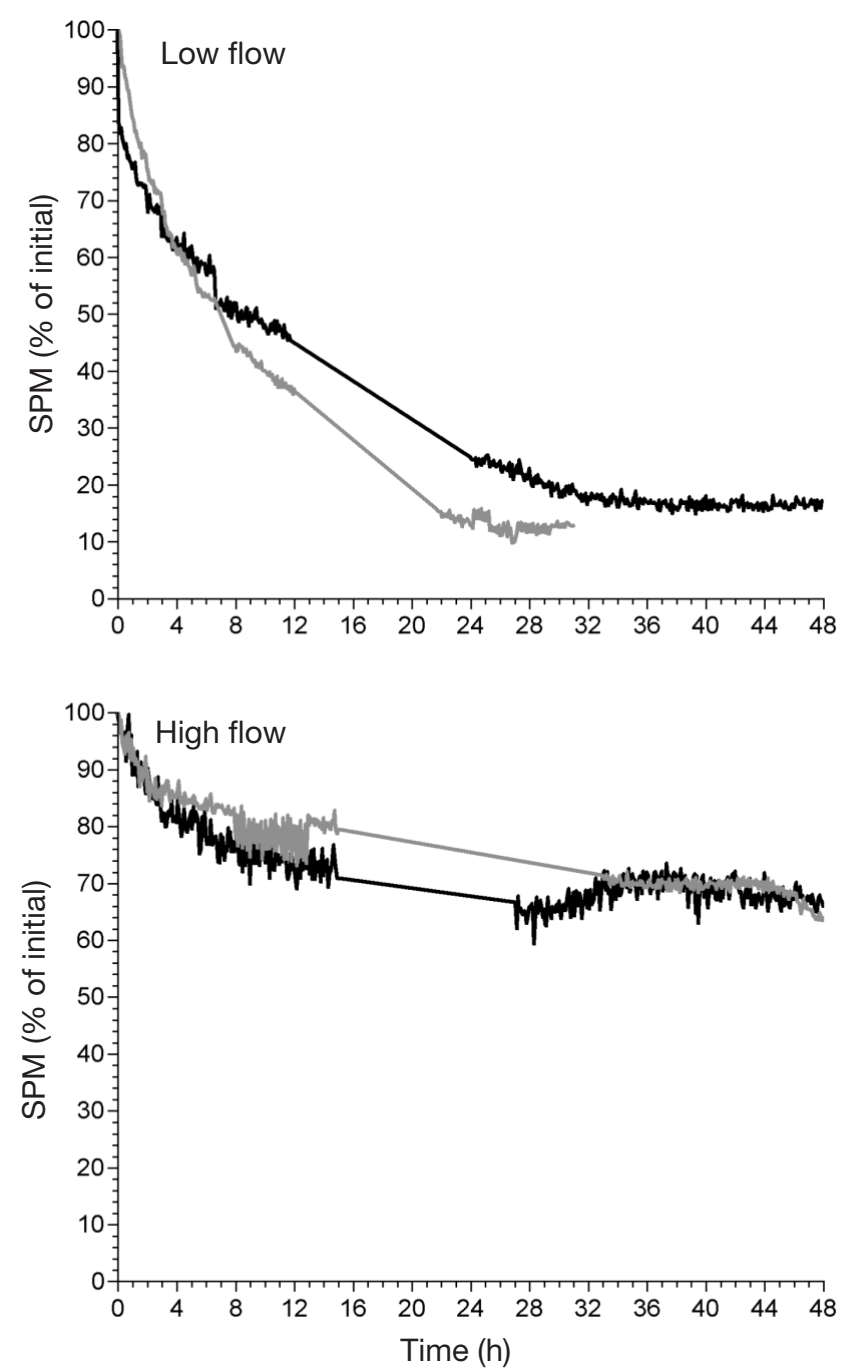

Fig. 4. Removal efficiency of the phosphatic clay IMC-P as the $\%$ of total suspended particulate matter (SPM), assumed to be $100 \%$ IMC-P at an initial concentration of $\sim 0.25 \mathrm{~g} \mathrm{DW} \mathrm{l}^{-1}$, over time as measured by optical backscatter (OBS). Black lines correspond to the clay-only control trial and gray lines are the clay-algae treatments 
system may account for this decline, but likely an equilibrium between sedimentation and resuspension of particles was reached at $\sim 30 \%$ removal for these concentrations (4000 cells $H$. triquetra $\mathrm{ml}^{-1}, 0.25 \mathrm{~g}$ IMC-P $\mathrm{DW}^{-1}$ ) and the particular flume system (Fig. 4).

\section{Particle characteristics}

Particle size distributions were determined from the product of particle volume as calculated from the ECD, and particle number counts for the clay-only control and clay-algae treatment trials at 3 and $24 \mathrm{~h}$ for both flow regimes (Fig. 5). Regardless of the presence of Heterocapsa triquetra or the sampling time, the distributions were similar for both the clay-only control and clay-algae trials within each flow regime. No distinct peak at $\sim 15 \mu \mathrm{m}$ ECD occurred in the clay-algae treatments, indicative of $H$. triquetra cells; rather the simi-
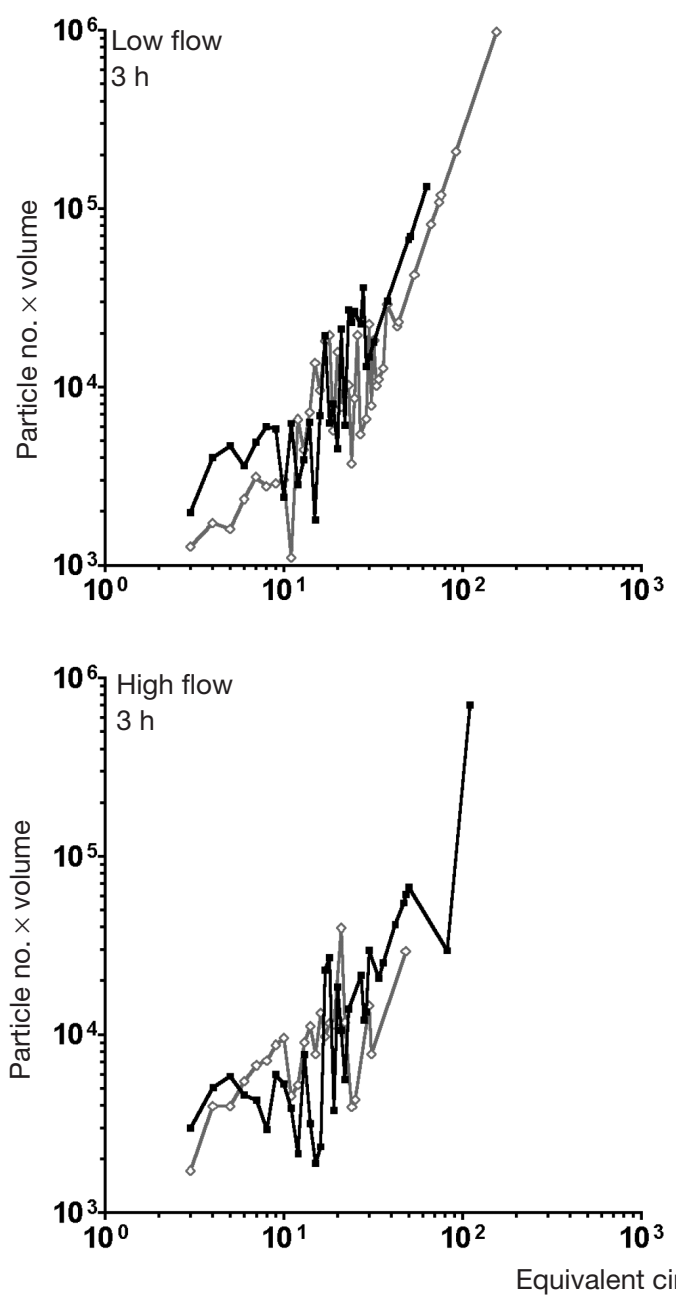

Fig. 5. Particle size distributions as the product of particle number and volume per equivalent circular diameter (ECD) bin size converted from small volume particle microsampler (SVPM) image analysis. Clay-only control ( $\longrightarrow$ ); clay-algae treatment with Heterocapsa triquetra cells present in the distribution $(\diamond \Longleftrightarrow)$ larity to the clay-only controls suggests that clay-clay flocculation occurs and contributes to the large (>10 $\mu \mathrm{m}$ ECD) particle-size spectrum.

The median ECD was calculated by converting the median area from SVPM particle distributions for the low and high-flow regimes over time (Fig. 6). The distributions shown were modified in all cases by deleting areas corresponding to particles $<4 \mu \mathrm{m}$ attributed to non-aggregated IMC-P particles (see distribution in Fig. 2B) in order to reduce the influence of this large proportion of small particles on the median ECD. The treatment distributions were further modified by deleting the values corresponding to Heterocapsa triquetra cells. The particles attributed to algal cells were identified by fluorescence as described in the methods. The resulting size distribution had a median particle ECD ranging between 5 and $8 \mu \mathrm{m}$ at all times for both the corrected low- and high-flow regimes. In most cases, the median ECD was slightly less for the clay-only control than the
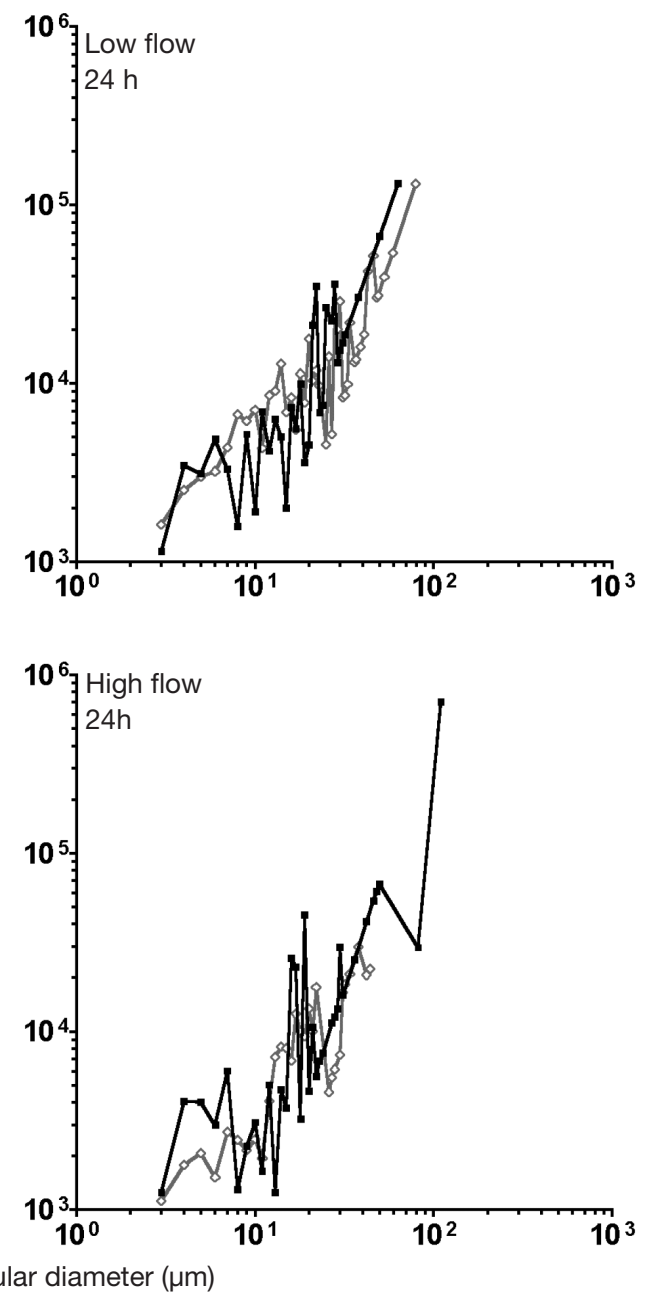

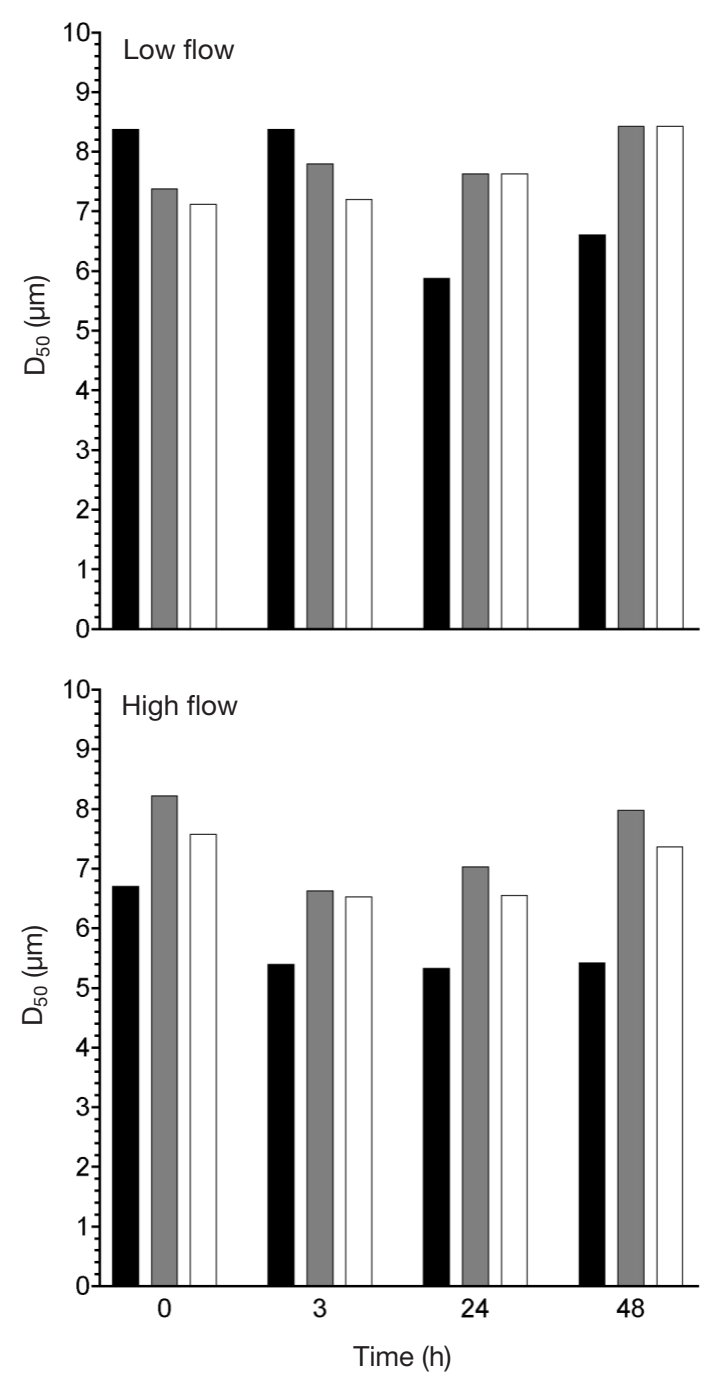

Fig. 6. Median $\left(\mathrm{D}_{50}\right)$ equivalent circular diameter $(\mathrm{ECD})$ determined from the median area of small volume particle microsampler (SVPM) particle-size distributions, with clay particles $<4 \mu \mathrm{m}$ removed. Clay-only control (ם); clay-algae treatment with Heterocapsa triquetra cells present in the distribution $(\square)$; clay-algae treatment without $H$. triquetra cells present in the distribution, where cells were identified through fluorescence $(\square)$

clay-algae treatment in both low flow and high flow (Fig. 6). Inconsistencies in this trend can be attributed to large flocs present early in the trials, which eventually sediment out (Fig. 6). In all cases, modifying the distributions from SVPM analysis by removing the areas attributed to $H$. triquetra, did not significantly change the median ECD. This comparison suggests that the large end of the particle size spectrum did not result from algal-only or clay-algal flocs, but rather large clay-clay aggregates. In both the low- and high-flow regimes, there was no evidence that algal cells were aggregated to each other. Additionally, algal cells did not show the presence of a detectable clay layer on the cell surface.

\section{DISCUSSION}

The concept behind mitigating HABs by treatment with clays is based on the mutual aggregation between the algae and the mineral particles leading to the formation of large flocs that settle to the bottom (Avnimelech et al. 1982, Degens \& Ittekot 1984). A number of studies have demonstrated that fine dispersions of clay minerals can effectively remove algal cells from seawater (Avnimelech et al. 1982, Søballe \& Threlkeld 1988, Sengco et al. 2001). Several of these studies have shown that some species are removed more efficiently than others and that the removal rate depends on clay type, clay concentration, algal type and algal concentration (Avnimelech et al. 1982, Sengco et al. 2001). The mechanism underlying this differential removal is poorly understood. Although these studies suggest that flocculation between algal cells and clay particles occurs, no effort has been made to quantify the in situ particle-size distribution or composition in turbulent flow. These studies were often conducted in static systems, e.g. test tubes, where flow and shear were not considered as agents of particle aggregation and disaggregation, and wall effects are known to occur (Sengco et al. 2001). In our laboratory study, differential removal of the dinoflagellate Heterocapsa triquetra by the phosphatic clay IMC-P in 2 flow regimes is demonstrated, pointing to the importance of flow conditions in evaluating the site-specific effectiveness of clay mitigation. It is difficult to make direct comparisons with previous work given the differences in scale and experimental design. Further studies are needed to assess the relevance of scale and of varying flow conditions in predicting HAB removal by clay in the field.

\section{Heterocapsa triquetra removal efficiency}

The phosphatic clay IMC-P effectively removes the thecate dinoflagellate Heterocapsa triquetra in a lowflow environment $\left(<2 \mathrm{~cm} \mathrm{~s}^{-1}\right)$. In this flow regime, the population of 'healthy' algal cells grew over time in the absence of clay. The data suggest that cell physiological condition plays an important part in determining cell removal from the water column. The third algaecontrol showed that if cells are in poor condition, for example with old or 'shocked' cultures, removal by the clay may be amplified. In the current research, swimming ability was used as an indicator of cell physiological condition. This is an important factor in determining the removal efficiency of algal cells and needs to be considered as a potential source of variability in future studies. Many phytoplankters, including dinoflagellates, are classified as 'strong swimmers' and may avoid or break free from sticky clay particles, and 
ultimately remain in the water column. It was shown that freshwater Euglena gracilis had only a slight tendency for flocculation, probably because of its vigorous motility (Avnimelech et al. 1982). However, Chlamydomonas, a less motile alga, formed clusters and sedimented readily with clay. $H$. triquetra is a fairly strong swimmer with an average swimming speed of $0.21 \mathrm{~mm}$ $\mathrm{s}^{-1}$ (Sengco 2001); however, results of the present study suggest that it quickly shows a reduction in swimming ability in the presence of clay and increased flow. Similar experiments to those described in the present study were conducted in the flume using the thecate dinoflagellate Prorocentrum micans as the test organisms (unpubl. data), showing that the swimming ability of cells was not affected and that they were not removed effectively by IMC-P in static conditions (also M. R. Sengco pers. comm.).

Sengco (2001) examined collision frequencies and algal removal rates as a function of swimming speed for flagellates, non-motile diatoms and small cocci in the presence of clay in static systems. Clay concentration was an important factor in cell removal efficiency. At relatively low clay concentration $\left(<0.03 \mathrm{~g} \mathrm{l}^{-1}\right)$, Karenia brevis cells were able to free themselves from the clay, swim away and resume vegetative growth; however, in contrast, mortality resulted at high clay loadings $\left(>0.50 \mathrm{~g} \mathrm{l}^{-1}\right.$ ) (Sengco 2001). It was concluded that mortality was caused by direct physical contact between the cells and clays, but the exact mechanism by which surface interactions lead to cell death is unknown. It is suggested that clay potentially disrupts motility by adhering to the flagella (M. R. Sengco pers. comm); however, this has yet to be examined conclusively. Avnimelech et al. (1982) speculated that the mutual aggregation of algae and clay particles was a widespread phenomenon and that the variable flocculating potential of different algae (Cuker 1987, Søballe \& Threlkeld 1988, Sengco et al. 2001) depends on the composition and properties of the cell wall, on the extent and type of excretions, physiological conditions, age, and other factors.

The present study shows that at higher flow $(\sim 13 \mathrm{~cm}$ $\left.\mathrm{s}^{-1}\right)$, IMC-P is not as effective in removing algal cells, as indicated by the similar removal of Heterocapsa triquetra in the water column in the presence or absence of clay. Irrespective of the presence of clay, the algal cells suffered stress indicated by the decrease in swimming ability. Therefore, in this flow regime, the removal mechanism appears to be dictated by the physiological stress on $H$. triquetra resulting from the effects of high current speed and/or high fluid shear and not the presence of IMC-P. Smayda (2002) indicated that in the field there are zones of vertical velocity rates (increased turbulence) at which, based on their motility, dinoflagellates would survive and bloom.
A review of 71 clones and species of dinoflagellates, phytoflagellates and protoperidinians, showed that the majority (59\%) swim at rates which exceed an upwelling velocity of $0.125 \mathrm{~mm} \mathrm{~s}^{-1}$. The results suggest that $H$. triquetra cells swam easily at low flow, but were unable to overcome shear rates at high flow. Several studies have shown that increased turbulence results in a decrease in cell growth rates and an increase in mortality (Thomas \& Gibson 1990, Berdalet 1992, Juhl et al. 2000, 2001). Berdalet (1992) suggested that the physiological processes linked to nutrient uptake, biosynthetic metabolism and cellular growth are responsible for observed decreased growth rates.

Turbulence, which breaks apart as well as aggregates particles, has been suggested as the mechanism that determines the maximum size of flocs (Tambo \& Hozumi 1979, Eisma 1986, Manning \& Dyer 1999, Manning et al. 2001). Although an initial application of clay to HABs may aggregate particles in the presence of turbulence, a balance between aggregate formation and aggregate breakup may result in cells escaping floc formation and therefore, resulting in low removal efficiencies. Alternatively, breakup of flocs and cell escape could occur when encountering near-bottom shear after the successful aggregation and removal of cells in a relatively low flow regime. Much of the past research on cell removal efficiencies with clay has been conducted in static systems. These experiments demonstrate that removal efficiencies are highly dependent on flow. This may ultimately be the determining factor in successful removal of HABs, but requires further investigation over a range of current velocities.

\section{SPM removal efficiency and particle characteristics}

Regardless of the presence of algae, the largest fraction of suspended particulate matter was almost completely removed from the water column in the low-flow regime. In contrast, the SPM in the high-flow regime reached a steady state concentration $(70 \%$ of the initial concentration) over the $48 \mathrm{~h}$ irrespective of the presence of Heterocapsa triquetra. The initial loss could also be explained by trapped clay in areas of the flume, such as unknown features in the return pipe, and in the boxed sand (Pilditch et al. 1998).

Particle size is an important variable to quantify in these experiments and relevant to characterize exposure conditions in subsequent benthic impact studies on lethal and/or sublethal effects of clay mitigation on juvenile bivalves. The data from the size-frequency distributions were used to identify the size range of particles that benthic organisms would be exposed to during the mitigation event in the 2 flow regimes. This parameter becomes important in predicting the feed- 
ing behavior of suspension-feeding fauna exposed to increased particle flux to the bottom. For example, bivalve particle retention efficiency and subsequent selection and/or rejection of particles depend partly on particle size. White (1997) showed that adult sea scallops Placopecten magellanicus consistently removed water-based drilling fluid waste particles that were flocculated at greater rates than unflocculated particles. Most bivalves including hard clams retain $100 \%$ of particles $>3 \mu \mathrm{m}$ on the gill, but the minimum size at which scallops attain $100 \%$ retention efficiency is $\sim 5 \mu \mathrm{m}$ (reviewed by Grizzle et al. 2001). The present study indicated that in both the low- and high-flow regimes, clay particles, via formation of clay-clay flocs, are available for retention on gills of suspension-feeding bivalves and thus, potentially could affect feeding behavior and particle availability (Archambault 2002).

Particle size distribution did not vary between the clay-control and treatments (IMC-P with Heterocapsa triquetra) within flow regimes and sampling times. Several explanations for the lack of clay-algal aggregation are suggested, as evidenced from SVPM filter photographs. Shear disturbance in the flume could account for the lack of large aggregates. Thomas et al. (1999) suggested that in a flocculator stirred with an impeller, high values of strain occur close to the tip of the impeller. It is probable that breakage occurs in these regions of high shear intensity rather than in the more quiescent areas away from the impeller. The airline inserted in the return flow pipe could potentially also account for some breakage of particles via production of air bubbles.

The flume used in the experiment did not allow for the formation of a well defined benthic boundary layer. At higher rheostat speeds (>500 rpm), a central jet was developed as the water entered the main body of the flume from the return pipe. The flow straighteners did not fully rectify the flow, resulting in potentially static flow areas where material may have deposited, as evidenced by the slight removal of clay in the high-flow regime. Despite these caveats (turbulent flow), clay was effective in removing Heterocapsa triquetra cells from the water column in the absence of algal-clay flocs; thus, supporting the hypothesis that other mechanisms (e.g. surface interactions) may be contributing to HAB removal. Few laboratory flocculators, including flumes, operate with laminar flow (Thomas et al. 1999), and both laminar and turbulent flow are of interest in the context of clay control of HABs. Turbulent particle interactions are still poorly understood, but the isotropic model has been successfully adopted in flocculation modeling. The model describes turbulence as a cascade of eddies of diminishing size (Thomas et al. 1999). Based on this model and experimental data, Casson \& Lawler (1990) concluded that smaller particles were far more likely to collide with one another than with larger particles; therefore, the smaller clay particles $(\sim 2 \mu \mathrm{m}$ ESD) were more likely to aggregate together (as shown in the present study) than with $H$. triquetra cells. Sengco (2001) speculated that in the application of clay to the brown tide alga Aureococcus anophagefferens, the small clay particles aggregated quickly and were removed without colliding and flocculating with the cells, resulting in less effective removal of $A$. anophagefferens from the water column. Increasing the agitation (mixing) kept the initial clay size small, i.e. no initial clay aggregation and removal, and increased collision rates with cells, thus increasing the removal efficiency of $A$. anophagefferens.

Previous research conducted by Sengco et al. (2001) on the removal efficiencies of clay on Karenia brevis and Aureococcus anophagefferens suggested that the use of coagulants or flocculants in the clay treatment increases cell removal efficiency. In theory, coagulants and flocculants promote flocculation by affecting the surface chemistry (stickiness) of the particles, thus resulting in increased particle aggregation. Ideally the use of these substances would decrease the total clay loading required to remove HABs and might reduce benthic impacts from sedimenting or resuspended particles. Sengco et al. (2001) suggested that polyaluminum chloride (PAC) at $5 \mathrm{ppm}$ was the most effective in removing $K$. brevis. The addition of PAC to clay treatments could potentially increase the removal efficiency of Heterocapsa triquetra by IMC-P clay, especially in the high-flow regime, by increasing the occurrence of large clay-algal aggregates.

Here, we observed that the SVPM did not effectively capture dinoflagellate cells which led to the underestimation of the absolute concentration of dinoflagellate cells. Therefore, the particle distributions may not accurately describe the relative contribution of Heterocapsa triquetra cells to the large end of the particle size spectrum. Archambault et al. (2001) implied that the SVPM could be used to calculate particle concentration, but suggested that, depending on particle type, concentration thresholds of the suspension determined the effectiveness of the SVPM in calculating particle concentration. At 4000 cells ml$^{-1}$, the concentration of $H$. triquetra cells could have been too low for the SVPM to sample accurately. Motile algal cells may also actively avoid the solenoid mechanism and this could result in reduced capture of cells. Further investigations on the effectiveness of the SVPM in determining absolute particle concentrations of large motile cells and its dependence on particle concentration thresholds are required. Despite these caveats, the findings using the SVPM method that dinoflagellate cells were never incorporated in larger aggregates even at low flow remains valid. 
In summary, the application of clay to HABs is a promising method for reducing environmental and economic impacts from HABs, but is more likely to be effective in relatively low-energy environments. Despite the inherent limitations in flume design outlined above (most notably in terms of propeller-driven flow and associated shear stress), several important findings emerge from this study which will be useful in guiding future research and interpreting results of clay applications in the field. At low flow, Heterocapsa triquetra cells sedimented from the water column in response to clay addition despite the demonstrated lack of formation of clay-algal aggregates. This suggests the existence of alternate mechanisms for clayinduced algal removal, e.g. entrainment by clay-clay aggregates or direct contact of clay particles on the cell surface leading to physico-chemical interactions that could impair cell motility. Evidence of the latter was detected in our study although motility was only determined qualitatively. $H$. triquetra sedimentation was also found to occur in 1 out of 3 low-flow controls, and the anomaly was associated with reduced cell motility. This finding suggests that differences in the physiological condition of cells may lead to variable results both in the laboratory and in the field, and need to be considered in future work. In contrast to results obtained in the low-flow regime, no significant removal of $H$. triquetra by clay occurred at high flow. This may be due to the high current speed and/or high shear generated in the experimental flume in this treatment. Since turbulent mixing and shear may occur in the field, it will be important in future studies to determine the effects of both of these variables, horizontal current speed and shear, potentially using less disruptive experimental flumes, in controlling the effectiveness of HAB removal by clays.

Acknowledgements. We thank R. Jordan, M. Anderson, S. McKenna, D. van der Meer and S. MacQuarrie from the Institute for Marine Biosciences (IMB), National Research Council of Canada (NRC), and B. Schofield from Dalhousie University for their technical support and assistance in various aspects of this work. Thanks to B. Hargrave at the Bedford Institute of Oceanography for the use of his fluorescent microscope for the past 2 yr. P. Hill, Department of Oceanography, Dalhousie University, provided valuable advice which greatly benefited this work. We extend our thanks to Don Anderson, Woods Hole Oceanographic Institution (WHOI), for his comments and input into the research, and WHOI postdoctoral fellows Stace Beaulieu, Aishao Li and especially Mario Sengco for providing the clay as well as valuable unpublished information used in experimental design. This project was funded by ECOHAB-EPA (US EPA grant No. R-82551-01-01) via a subcontract from WHOI (D. Anderson) to V.M.B. at IMB, NRC. Supplementary student support was provided by a Dalhousie University Graduate Fellowship and a Natural Sciences and Engineering Research Council of Canada (NSERC) Graduate Research Award.

\section{LITERATURE CITED}

Alldredge AL, Passow U, Logan BE (1993) The abundance and significance of a class of large, transparent organic particles in the ocean. Deep-Sea Res Part I 40: 1131-1140

Alldredge AL, Passow U, Haddock SHD (1998) The characteristics and transparent exopolymer particle (TEP) content of marine snow formed from thecate dinoflagellates. J Plankton Res 20:393-406

Anderson DM (1997) Turning back the harmful red tide. Nature 388:513-515

Archambault MC (2002) The effects of clay used in the mitigation of harmful algal booms on the growth rate of juvenile hard clams (Mercenaria mercenaria). MSc thesis, Dalhousie University, Halifax, NS

Archambault MC, Grant J, Hatcher A (2001) The small volume particle microsampler (SVPM): a new approach to particle size distribution and composition analyses. DeepSea Res Part I 48:2331-2346

Avnimelech Y, Menzel RG (1984) Coflocculation of algae and clay to clarify turbid impoundments. J Soil Water Conserv 9:200-203

Avnimelech Y, Troeger BW, Reed LW (1982) Mutual flocculation of algae and clay: evidence and implications. Science 216:63-65

Bae HM, Choi H, Lee WC, Yoon SJ (1998) Control of the red tide by yellow loess dispersion. In: Kim HG, Lee SG, Lee CK (eds) Proc Korea-China Joint Symp on Harmful Algal Blooms, Pusan, Korea, Dec 5 to 7, 1997. Natl Fish Res Dev Inst (Korea), Pusan, p 53-60

Berdalet E (1992) Effects of turbulence on the marine dinoflagellate Gymnodinium nelsonii. J Phycol 28:267-272

Bromwell LG (1982) Physico-chemical properties of Florida phosphatic clays. Florida Institute of Phosphate Research, Contract No. 80-02-003, Bartow, FL

Casson LW, Lawler DF (1990) Flocculation in turbulent flow: measurement and modelling of particle size distributions. J Am Water Works Assoc 63:54-68

Choi HG, Lee PY, Yun SJ, Lee WC, Bae HM (1999) Control of Cochlodinium polykrikoides blooms and adsorption of nutrients in the seawater by clay and yellow loess. Bull Natl Fish Res Dev Inst (Korea) 57:105-110

Cuker BE (1987) Field experiment on the influences of suspended clay and $\mathrm{P}$ on the plankton of a small lake. Limnol Oceanogr 32:840-847

Degens ET, Ittekot V (1984) A new look at clay-organic interactions. Mitt Geologisch-Palaeontologischen Inst Univ Hamburg 56:229-248

Dyer KR, Manning AJ (1999) Observation of the size, settling velocity and effective density of flocs, and their fractal dimensions. J Sea Res 41:87-95

Eisma D (1986) Flocculation and de-flocculation of suspended matter in estuaries. Neth J Sea Res 20:183-199

Grizzle RE, Bricelj VM, Shumway SE (2000) Physiological ecology of Mercenaria mercenaria. In: Kraeuter JN, Castagna M (eds) Biology of the hard clam. Elsevier Science Publishers, Amsterdam, p 305-382

Guillard RRL, Hargraves PE (1993) Stichochrysis immobilis is a diatom, not a chrysophyte. Phycologia 32:234-236

Hallegraeff GM (1993) A review of harmful algal blooms and their apparent global increase. Phycologia 32:79-99

Howell BR, Shelton RGJ (1970) The effect of China clay on the bottom fauna of St. Austell and Mevagissey bays. J Mar Biol Assoc UK 50:593-607

Jackson GA, Lochmann S (1993) Modeling coagulation of algae in marine ecosystems, 2nd edn. In: Buffle J, van 
Leeuwen HP (eds) Environmental particles. Lewis Publishers, Boca Raton, FL, p 387-414

Juhl AR, Velasquez V, Latz MI (2000) Effect of growth conditions on flow-induced inhibition of population growth of a red-tide dinoflagellate. Limnol Oceanogr 45:902-915

Juhl AR, Trainer VL, Latz MI (2001) Effect of fluid shear and irradiance on population growth and cellular toxin content of the dinoflagellate Alexandrium fundyense. Limnol Oceanogr 46:758-764

Kim HG (1998) Cochlodinium polykrikoides blooms in Korean coastal waters and their mitigation. In: Reguera B, Blanco J, Fernandez M, Wyatt T (eds) 8th Int Conf on Harmful Algae, Vigo, Jun 25 to 29, 1997. Xunta de Galicia (Spain) and the Intergovernmental Oceanographic Commission (IOC), Vigo, p 227-228

Kim HG, Park JS, Lee SG, An KH (1993) Population cell volume and carbon content in monospecific dinoflagellate blooms. In: Smayda TJ, Shimizu Y (eds) Proc 5th Int Conf on Toxic Marine Phytoplankton, Newport, RI, October 28 to November 1, 1991. Elsevier Science Publishers, Amsterdam, p 769-773

Lindholm T, Nummelin C (1999) Red tide of the dinoflagellate Heterocapsa triquetra (Dinophyta) in a ferry-mixed coastal inlet. Hydrobiologia 393:245-251

Manning AJ, Dyer KR (1999) A laboratory examination of floc characteristics with regard to turbulent shearing. Mar Geol 160:147-170

Manning AJ, Dyer KR, Christie M (2001) Properties of macroflocs in the lower reaches of the Gironde estuary. In: Elbee $\mathrm{Jd}^{\prime}$, Prouzet P (eds) Proc 7th Int Symp on Oceanogr of the Bay of Biscay, Biarritz, France, April 4 to 6, 2000. Ifremer, Plouzané, p 230-235

McCave IN (1984a) Erosion, transport and deposition of fine-grained marine sediments. In: Stow DAV, Piper DJW (eds) Fine-grained sediments: deep-water processes and facies, Vol 15. Blackwell Scientific Publications, Oxford, p 35-69

McCave IN (1984b) Size spectra and aggregation of suspended particles in the deep ocean. Deep-Sea Res Part I 31:329-352

Na G, Choi W, Chun Y (1996) A study on red tide control with Loess suspension. J Aquaricult 9:239-245

Passow U, Alldredge AL (1994) Distribution, size and bacterial colonization of transparent exopolymer particles (TEP) in the ocean. Mar Ecol Prog Ser 113:185-198

Passow U, Alldredge AL, Logan BE (1994) The role of particulate carbohydrate exudates in the flocculation of diatom blooms. Deep-Sea Res Part I 41:335-357

Pilditch CA, Emerson CW, Grant J (1998) Effect of scallop

Editorial responsibility: Otto Kinne (Editor),

Oldendorf/Luhe, Germany shells and sediment grain size on phytoplankton flux to the bed. Cont Shelf Res 17:1869-1885

Portman JE (1970) The effect of China clay on the sediments of St. Austell and Mevagissey bays. J Mar Biol Assoc UK 50:577-591

Russ JC (ed) (1995) The image processing handbook, 2nd edn. CRC Press, Boca Raton, FL

Sengco MR (2001) The aggregation of clay minerals and marine microalgal cells: physicochemical theory and implications for controlling harmful algal blooms. PhD thesis, Massachusetts Inst Technol at Woods Hole Oceanographic Institution, Woods Hole, MA

Sengco MR, Li A, Tugend K, Kulis D, Anderson DM (2001) Removal of red and brown tide cells using clay flocculation: 1. Laboratory culture experiments with Gymnodinium breve and Aureococcus anophagefferens. Mar Ecol Prog Ser 210:41-53

Smayda TJ (2002) Turbulence, watermass stratification and harmful algal blooms: an alternative view and frontal zones as 'pelagic seed banks'. Harmful Algae 1:95-112

Søballe DM, Threlkeld ST (1988) Algal-clay flocculation in turbid waters: variations due to algal and mineral differences. Verh Int Ver Limnol 23:750-754

Stewart ARJ (1999) Aquaculture impact: disaggregation and settling velocity of salmon feed. MSc thesis, Dalhousie University, Halifax, NS

Tambo N, Hozumi H (1979) Physical characteristics of flocs-II. Strength of floc. Water Res 13:421-427

Thomas DN, Judd SJ, Fawcett N (1999) Flocculation modelling: a review. Water Res 33:1579-1592

Thomas WH, Gibson CH (1990) Quantified small-scale turbulence inhibits a red tide dinoflagellate, Gonyaulax polyedra Stein. Deep-Sea Res Part I 37:1583-1593

White MJ (1997) The effect of flocculation on the size-selective feeding capabilities of the sea scallop Placopecten magellanicus. MSc thesis, Dalhousie University, Halifax, NS

Yu Z, Zou J, Ma X (1994a) Application of clays to removal of red tide organisms. I. Coagulation of red tide organisms with clays. Chin J Oceanol Limnol 12:193-200

Yu Z, Zou J, Ma X (1994b) Application of clays to removal of red tide organisms. II. Coagulation of different species of red tide organisms with montmorillonite and effect of clay pretreatment. Chin J Oceanol Limnol 12:316-324

Yu Z, Zou J, Ma X (1995) Application of clays to removal of red tide organisms. III. The coagulation of kaolin on red tide organisms. Chin J Oceanol Limnol 13:62-70

Yu Z, Sun X, Song X, Zhang B (1999) Clay surface modification and its coagulation of red tide organisms. Chin Sci Bull 44:617-620

Submitted: July 9, 2002; Accepted: January 13, 2003

Proofs received from author(s): April 23, 2003 